\title{
Antimicrobial Susceptibility Pattern among Aerobic Gram Negative Bacilli of Lower Respiratory Tract Specimens of a Tertiary Care Hospital in Southern Rajasthan, India
}

\author{
Manjula J. Barbriya and Neelam Chauhan* \\ Department of Microbiology, Pacific institute of Medical Science (PIMS), \\ Udaipur, Rajasthan, India \\ *Corresponding author
}

\begin{abstract}
A B S T R A C T
Lower Respiratory tract infections (LRTI's) are the most frequent infections among patients. The consequences of increased drug resistance are far reaching since bacterial infection of the respiratory tract (RT) is a major cause of death from infectious disease. The present study was conducted to determine the bacterial etiology and their

Keywords

Antibiotic susceptibility, Gram-negative bacteria, Lower respiratory tract infection

Article Info

Accepted: 20 May 2018 Available Online: 10 June 2018 antimicrobial susceptibility pattern of Gram negative bacteria in lower respiratory tract infections so as to update the clinicians in the various antimicrobial alternatives available in the treatment. Patients with lower respiratory tract infections were collected in time span of six months. Bacterial pathogens were isolated from sputum and tracheal specimens, and subjected to antibiotic susceptibility testing, using standard bacteriologic techniques. Out of samples obtained from 442 patients, 150 (33.93\%) were culture positive. 315 samples yielded no growth. 127 were Gram-negative bacilli (GNB-28.73\%). 23 were Gram positive cocci. The common GNB isolates were non-fermentative gram-negative bacilli Pseudomonas aeruginosa (34.64\%), followed by Klebsiella spp. (31.49 \%) and Acinetobacter spp. (15.74\%). GNB isolates from sputum and endotracheal aspirates were $85(66.92 \%)$ and $42(33.07 \%)$ respectively. Maximum no. of patients were from 46-60 age group (35.43\%) followed by $61-75$ age group $(25.98 \%)$.Gram negative isolates showed high susceptibility with Colistin, Imipenem, Ciprofloxacin, Gentamicin, Levofloxacin, Amikacin. For effective management of LRTIs bacteriological diagnosis and antibiotic susceptibility pattern is indispensable.
\end{abstract}

\section{Introduction}

Respiratory tract infections are common and perhaps the most frequently reported of all human infections. They are traditionally divided into two: upper respiratory tract infections and lower respiratory tract infections. Most of these infections are mild, transient and sometimes self-limiting, while others may be chronic. (Ndip et al., 2008) Lower respiratory tract infections (LRTIs) occur below the level of the larynx, i.e. in the trachea, the bronchi, or in the lung tissue. They include conditions such as tracheitis, bronchitis, bronchiectasis, lung abscess, tuberculosis, pneumonia (World Health Organisation, 2003). It usually occurs when infecting organisms reach the airway of 
pulmonary parenchyma by passing the mechanical and other nonspecific barriers of the upper respiratory tract. Infection may result from inhalation of infectious aerosols, aspiration of oral or gastric contents or by heterogeneous spread (Mahon et al., 2007) In India, ARI (Acute respiratory infection) is responsible for one million deaths. (Sclwyn, 1990) Out of these $10-15 \%$ are due to acute lower respiratory tract infections (ALRTI). (Reddiah and Kapoor, 1988) Clinicians have traditionally utilized expectorated sputa and sometimes tracheal-aspirate specimens to diagnose and treat lower respiratory tract infections (LRTI). Lower Respiratory Tract Infection (LRTI) is one of the leading causes of the morbidity and mortality in the world. LRTI is not a single disease but a group of specific infection each with a different epidemiology, pathogenesis, clinical presentation and outcome. The etiology and symptomatology of respiratory diseases vary with age, gender, season, the type of population at risk and other factors' (Mishra et al., 2012)

Among 20 most frequent causes of death, ischemic heart disease and cerebrovascular disease are the leading causes of death, followed by lower respiratory infections (including pneumonia), chronic obstructive pulmonary disease and diarrhoeal diseases. It is estimated that 4.2 million deaths occurs each year due to LRTI. (World Health Organization, 2004) Several studies (Gauchan et al., 2006; Kim et al., 2005; Egbagbe and Mordi, 2006) have been conducted throughout the world to derive information about etiological agents of LRTI and their antimicrobial susceptibility pattern. No study can speculate exactly the situation of LRTI among the different people of different parts of world. Out of the total acute respiratory diseases, 20-24\% of all deaths are accounted for by Lower Respiratory Tract infection. Prevalent flora and antimicrobial resistance pattern may vary from region to region depending upon the antibiotic pressure in that locality. Therefore, the present study was designed to know the bacterial profile and determine the antimicrobial susceptibility pattern among the aerobic GNB isolated from LRT of patients admitted to our institute. Current knowledge of bacterial etiology and microbial susceptibility would help reduce the indiscriminate antibiotic use and result in better therapeutic outcome and decrease in development of resistance.

The objective of the present study is

To find out the Gram negative bacteriological spectrum in Lower Respiratory Tract Infection among the patients attending our setup.

To determine the pattern of antibiotic susceptibility of the isolates.

\section{Materials and Methods}

This was a hospital based retrospective study conducted on 442 sputum and endotracheal specimens received in the Laboratory of Microbiology Department, Pacific institute of medical science, Udaipur, Rajasthan within a period of 6 months (Nov.2017- April 2018). The study included 442 patients of all age group who had clinically evident lower respiratory tract infections. The Patients first morning sputum sample was collected directly into a sterile wide mouthed container and other specimen like endotracheal aspirates (E.T.) were received. Specimen transported to the laboratory according to standard protocol. The digested samples were cultured on Chocolate agar (CHA), 5\% Sheep Blood agar (BA) and MacConkey agar (MA) plates. The $\mathrm{CHA}$ and $\mathrm{BA}$ plates were incubated in $\mathrm{CO} 2$ incubator $(10 \% \mathrm{CO} 2)$ at $37^{\circ} \mathrm{C}$ for 24 hours while MA plates were incubated at $370 \mathrm{C}$ for 24 hours in aerobic atmosphere. All the bacteria were isolated and identified using 
morphological, microscopy and biochemical tests following standard procedures. (Betty A Forbes et al., Isenberg, 2004) All the respiratory isolates were tested for antibiotic susceptibility by Kirby-Bauer disc diffusion method in compliance with CLSI 2014 guidelines on Mueller Hinton agar plates. antibiogram of each confirmed isolate was studied and susceptibility results were compiled. (Clinical and Laboratory Standards Institute, 2018)

\section{Results and Discussion}

Out of the 442 sputum and endotracheal specimens submitted to Microbiology Laboratory of Pacific institute of Medical Science for bacterial culture and sensitivity, $150(33.93 \%)$ specimens showed the bacterial growth of which 127 were Gram negative bacilli (GNB) and 23 were Gram positive cocci (GPC).Now we are focossing on Gram negative bacteria. Among 127(28.73\%) patients of Gram negative bacilli, 101 male patients and 25 female patients were infected. Male affected more than female. Among 127 Gram negative bacilli, Pseudomonas spp $44(34.64 \%)$ was the most common isolates obtained followed by Klebsiella pneumoniae 40(31.49\%), Acinetobacter spp (20), E. coli (14), Citrobacter spp. (4), Steanotrophomonas spp. (2), Enterobacter spp (2), and serratia (1) Mostly affected age group is 46-60 year followed by 61-75 age group.

In case endotracheal specimen we have seen that Klebsiella is the most dominant pathogen $18(42.85 \%)$, out of 42 samples. In contrast to sputum Pseudomonas is predominant pathogen $38(44.70 \%)$, out of 85 samples followed by klebsiella 22(25.88\%). In antibiotic susceptibility we have found that Mostly bacteria showed sensitivity to Colistin, Imipenem Levofloxacin and gentamicin. Acinetobacter showed resistence to mostly drugs and susceptibility to Colistin and Imipenem.

In our study, out of 442 samples of sputum and endotracheal specimens 150(33.93\%) were showed growth on culture. Whereas 292 specimens showed no growth. Major cause of culture negativity in lower respiratory tract infections might be the prior use of antibiotics. The isolation growth rate is close to the observation of Sony et al., (2013) (30.42\%), Navaneet et al., (2002) (31.2\%), Okesola et al., (2008) (27\%), Sharma et al., (2004) $(39.46 \%)$ while Gauchan et al., (2006) (41.4\%), Dawadi et al., (2005) (48.43\%) and Egbagbe et al., (2006) (47.2\%) reported slightly higher isolation rate. Lower yield in the present study may be attributed to various factors. For example viruses like adenovirus, respiratory syncytial virus, parainfluenza virus and rhino virus, which are significant contributors of LRTI, were not looked for in our study due to limitation of resources. Likewise, common pulmonary pathogens such as Mycobacterium tuberculosis, Mycoplasma, Chlamydia, Pneumocystis, Fungi, Legionella, and anaerobes could not be cultured by routine methods.

Among 150 bacterial isolates, different types of bacteria GNB and GPC were identified. Greater number of the isolates was GNB, i.e. $127(28.73 \%)$, and $23(5.2 \%)$ were GPC. Out of 127 gram negative bacilli in total, Eight different GNB bacteria were isolated, giving the growth rate of $28.73 \%$. The bacteria isolated from the samples included Pseudomonas spp. (34.64\%), Klebsiella spp. (31.49\%), Acinetobacter spp. (15.74\%), Escherichia coli (11.02\%), Citrobacter spp. (3.14\%), Enterobacter spp and Steanotrophomanas. (1.57\%), and Serratia (0.78\%). Pseudomonas spp (34.64\%) was the most common isolate followed by Klebsiella spp. $(31.49 \%)$. 
Table.1 Pattern of bacterial isolation in different lower respiratory tract specimens and Distribution by gender

\begin{tabular}{|c|c|c|c|c|c|c|}
\hline $\begin{array}{c}\text { Total } \\
\text { no. of } \\
\text { samples } \\
\text { screene }\end{array}$ & & \multicolumn{2}{|c|}{$\begin{array}{l}\text { Total bacterial growth in samples } \\
\qquad(\text { GPC+GNB) }\end{array}$} & $\begin{array}{c}\text { No growth in } \\
\text { samples } \\
292\end{array}$ & \multicolumn{2}{|c|}{$\begin{array}{c}\text { Total bacterial } \\
\text { growth of Gram } \\
\text { negative bacteria } \\
\text { (GNB) }(\mathrm{n}=127)\end{array}$} \\
\hline 442 & \multicolumn{4}{|c|}{$150(33.93 \%)$} & Male & Female \\
\hline & \multirow{4}{*}{$\begin{array}{l}\text { Total } \\
\text { GPC } \\
(23)\end{array}$} & \multicolumn{3}{|c|}{ Total GNB (127) (28.73\%) } & \multirow{4}{*}{$\begin{array}{c}101 \\
(79.52 \%)\end{array}$} & \multirow{4}{*}{$\begin{array}{c}25 \\
(19.68 \%)\end{array}$} \\
\hline & & $\begin{array}{c}\text { Total \& } \\
\text { Type of } \\
\text { specimen }\end{array}$ & Total Sputum & Total E.T. & & \\
\hline & & 442 & 371 & 71 & & \\
\hline & & $\begin{array}{l}\text { Growth of } \\
\text { GNB in } \\
\text { samples } \\
(127)\end{array}$ & $\begin{array}{c}85 \\
(22.91 \%)\end{array}$ & $\begin{array}{c}42 \\
(59.15 \%)\end{array}$ & & \\
\hline
\end{tabular}

Table.2 Source of specimen and microbiological causes:

\begin{tabular}{|c|c|c|c|c|}
\hline Type of specimen & $\begin{array}{l}\text { No. of samples } \\
\text { tested }\end{array}$ & $\begin{array}{l}\text { No. of culture } \\
\text { positive of GNB } \\
(\%)\end{array}$ & \multicolumn{2}{|c|}{ Microorganism isolated } \\
\hline \multirow{8}{*}{ Sputum } & \multirow{8}{*}{371} & \multirow{8}{*}{$\begin{array}{l}85 \\
(22.91 \%)\end{array}$} & Pseudomonas spp. & 38 \\
\hline & & & Klebsiella spp. & 22 \\
\hline & & & Escherichia coli & 14 \\
\hline & & & Acinetobacter spp. & 5 \\
\hline & & & Citrobacter spp. & 2 \\
\hline & & & Steanotrophomonas & 2 \\
\hline & & & Serratia spp. & 1 \\
\hline & & & Enterobacter spp. & 1 \\
\hline \multirow{8}{*}{ E.T. } & \multirow{8}{*}{71} & \multirow{8}{*}{$\begin{array}{l}42 \\
(59.15 \%)\end{array}$} & Klebsiella spp. & 18 \\
\hline & & & Acinetobacter spp & 15 \\
\hline & & & Pseudomonas spp. & 6 \\
\hline & & & Citrobacter spp. & 2 \\
\hline & & & Enterobacter spp. & 1 \\
\hline & & & Steanotrophomonas & 0 \\
\hline & & & Serratia spp. & 0 \\
\hline & & & Escherichia coli & 0 \\
\hline Total & 442 & 127 & 127 & \\
\hline
\end{tabular}


Table.3 Age wise \& No. of isolates wise distribution of Isolates obtained from LRTI

\begin{tabular}{|c|c|c|c|c|c|c|c|c|c|}
\hline \multirow{2}{*}{$\begin{array}{l}\text { Age } \\
\text { group } \\
\text { (years) }\end{array}$} & \multicolumn{8}{|c|}{ Bacterial isolates $\mathbf{G N B}(\mathbf{n}=\mathbf{1 2 7})$} & \multirow{2}{*}{$\begin{array}{l}\text { Total age } \\
\text { wise } \%\end{array}$} \\
\hline & $\begin{array}{l}\text { Pseudo- } \\
\text { monas } \\
\text { spp. }\end{array}$ & $\begin{array}{l}\text { Kleb- } \\
\text { siella } \\
\text { spp. }\end{array}$ & $\begin{array}{l}\text { Acineto- } \\
\text { bacter } \\
\text { spp. }\end{array}$ & $\begin{array}{l}\text { Esche- } \\
\text { richia } \\
\text { coli. }\end{array}$ & $\begin{array}{l}\text { Citro } \\
\text { bacter } \\
\text { spp. }\end{array}$ & $\begin{array}{l}\text { Entero } \\
\text { bacter } \\
\text { spp. }\end{array}$ & $\begin{array}{l}\text { Steano } \\
\text { trophom } \\
\text { onas }\end{array}$ & Serratia & \\
\hline Up to 15 & 0 & 0 & 1 & 0 & 0 & 0 & 0 & 0 & $1(0.78)$ \\
\hline $16-30$ & 6 & 7 & 3 & 1 & 1 & 1 & 0 & 0 & $19(14.96)$ \\
\hline $31-45$ & 5 & 9 & 3 & 7 & 0 & 0 & 1 & 0 & 25 (19.68) \\
\hline $46-60$ & 16 & 11 & 9 & 4 & 3 & 1 & 1 & 0 & $45(35.43)$ \\
\hline 61-75 & 16 & 12 & 3 & 1 & 0 & 0 & 0 & 1 & 33 (25.98) \\
\hline$>75$ & 2 & 1 & 0 & 1 & 0 & 0 & 0 & 0 & $4(3.14)$ \\
\hline $\begin{array}{l}\text { Total no. } \\
\text { of } \\
\text { isolates } \\
\text { wise } \%\end{array}$ & $44(34.64)$ & $40(31.49)$ & $20(15.74)$ & $14(11.02)$ & $4(3.14)$ & $2(1.57)$ & $2(1.57)$ & $1(0.78)$ & 127 \\
\hline
\end{tabular}

Table.4 Antimicrobial susceptibility profiles of Gram negative bacilli in LTRI ( $\mathrm{n}=127)$

\begin{tabular}{|l|l|l|l|l|l|l|l|l|}
\hline $\begin{array}{l}\text { Anti } \\
\text { biotics }\end{array}$ & $\begin{array}{l}\text { Pseudo } \\
\text { monas } \\
(\mathbf{n = 4 4}) \\
\mathbf{S} \%\end{array}$ & $\begin{array}{l}\text { Klebsiella } \\
(\mathbf{n = 4 0}) \\
\mathbf{S} \%\end{array}$ & $\begin{array}{l}\text { Acineto } \\
\text { bacter } \\
(\mathbf{n = 2 0}) \\
\mathbf{S} \%\end{array}$ & $\begin{array}{l}\text { Esche } \\
\text { richia } \\
\text { coli } \\
(\mathbf{n = 1 4})\end{array}$ & $\begin{array}{l}\text { Citro } \\
\text { bacter } \\
(\mathbf{n = 4}) \\
\mathbf{S} \%\end{array}$ & $\begin{array}{l}\text { Entero } \\
\text { bacter } \\
(\mathbf{n = 2}) \\
\mathbf{S} \%\end{array}$ & $\begin{array}{l}\text { Steano } \\
\text { tropho } \\
\text { monas } \\
(\mathbf{n = 2}) \mathbf{S} \%\end{array}$ & $\begin{array}{l}\text { Serra } \\
\text { tia } \\
(\mathbf{n}=\mathbf{1}) \\
\mathbf{S} \%\end{array}$ \\
\hline AMIK & $31(70.45)$ & $18(45)$ & $2(10)$ & $6(42.85)$ & $2(50)$ & 0 & 0 & $1(100)$ \\
\hline GEN & $32(72.72)$ & $22(55)$ & $2(10)$ & $8(57.14)$ & $2(50)$ & 0 & 0 & $1(100)$ \\
\hline CIPRO & $33(75)$ & $8(20)$ & $4(20)$ & $2(14.28)$ & $2(50)$ & 0 & $1(50)$ & 0 \\
\hline AMC & - & $6(15)$ & - & 0 & 0 & 0 & 0 & 0 \\
\hline CAZ & $14(31.81)$ & $3(7.5)$ & $1(5)$ & $2(14.28)$ & $2(50)$ & 0 & 0 & 0 \\
\hline CTR & 0 & 10 & $2(10)$ & $3(21.42)$ & $2(50)$ & 0 & 0 & 0 \\
\hline CPM & $12(27.27)$ & 0 & $1(5)$ & $3(21.42)$ & $1(25)$ & 0 & 0 & $1(100)$ \\
\hline LEVO & $31(70.45)$ & $13(32.50)$ & 0 & $4(28.57)$ & $2(50)$ & 0 & $2(100)$ & $1(100)$ \\
\hline OFX & $31(70.45)$ & $12(30)$ & 0 & $2(14.28)$ & $2(50)$ & 0 & $1(50)$ & 0 \\
\hline IMIP & $37(84.09)$ & $27(67.50)$ & $6(30)$ & $11(78.57)$ & $2(50)$ & 0 & $1(50)$ & $1(100)$ \\
\hline MRP & $6(13.63)$ & $13(32.50)$ & $3(15)$ & $2(14.28)$ & $1(25)$ & 0 & - & - \\
\hline COT & - & $8(20)$ & 0 & $4(28.57)$ & $1(25)$ & $1(50)$ & $1(50)$ & $1(50)$ \\
\hline CL & $32(72.72)$ & $32(80)$ & $17(85)$ & $4(28.57)$ & $1(25)$ & $1(50)$ & $1(50)$ & $1(50)$ \\
\hline PIT & $29(65.90)$ & $15(37.50)$ & $2(10)$ & $8(57.14)$ & - & - & - & $1(50)$ \\
\hline TIC & $15(34.09)$ & $3(7.5)$ & $2(10)$ & $1(7.14)$ & $1(25)$ & - & - & - \\
\hline CEXM & - & $6(15)$ & 0 & $1(7.14)$ & 0 & - & - & - \\
\hline PI & $24(54.54)$ & $7(17.5)$ & 0 & - & - & - & - & - \\
\hline A/S & - & $4(10)$ & $1(5)$ & $1(5)$ & $1(5)$ & - & - & - \\
\hline
\end{tabular}

Abbreviations:

$\mathrm{n}$ - Total number of isolates, S-sensitive, AMK-Amikacin, GEN-Gentamicin, CIP-Ciprofloxacin, AMCAmoxicillin-clavulanate, CAZ-Ceftazidime, CTR-Ceftriaxone, CFM-Cefipime, LEVO-Levofloxacin, OF-Ofloxacin, IMP-Imipenem, MRP-Meropenem, COT-Cotrimoxazole, CL-Colistin, PIT-PiperacillinTazobactam, TIC-Ticarcillinclavulanate, A/S-Ampicillin-sulbactam, CFXM-Cefixime, PI- Piperacillin 
Infection with Pseudomonas is a serious problem affecting hospitalized patients, particularly those who are critically ill and immunocompromised, such as patients with cystic fibrosis. However, there were intermixing of hospital acquired and community acquired LRTI cases in our study.

This study was very much related to the similar study carried by Trupti bajpai et al., (2013), Nidhi goel et al., (2002) and Veena kumari et al., (2007). The isolation of Klebsiella as predominant organism also agrees with other studies carried out elsewhere.

Some studies have also pointed to the predominance of other gram negative bacilli in lower respiratory tract infection. For example, Gauchan et al., (2006) and Sharma et al., (2004) isolated Hamemophilus influenzae as the most common isolate while Okesola et al., (2008) and Egbagge et al., (2006) did Klebsiella pneumoniae. Though $H$. influenzae is regarded as a common pathogen incriminated in lower respiratory tract infection, we did not encounter any isolates of $\mathrm{H}$. influenzae in this study probably due to different environmental conditions and inadvertent use of antibiotics.

We have observed the infection rate in males $(79.52 \%)$ was higher than females (19.68\%) which revealed an increased susceptibility to the LRTIs in the male sex than in females as has been shown in (Table1), which was in comprehension with the findings of similar studies which were done by Shah et al., (2010) V Olugbue et al., (2011) and Akingbade (2012). Females enrolled in the study comprised largely of housewives. Since they were less mobile, they must have experienced less exposure to respiratory risk factors. Vulnerability of males may also be attributed to predisposing factors like smoking and alcoholism.
In this study majority of infected patients belonged to age group of 46-60 year (35.43\%) followed by 61-75year (25.98\%) age group shown in (Table 3), the observation being close to the findings of Serchan et al., (2018) who noticed that LRTI was found most prevalent in the age group of 50-59 year (21.3\%) while Sharma et al., (2004) reported it in the age group of 51-60 year. An increasing incidence of LRTI as they get older may be due to less effective immune system in older patients owing to either malnutrition or underlying degenerative diseases such as diabetes mellitus, emphysema, uraemia etc. means it is due to their age related physiological and immunological changes and other co-morbidities. The increasing resistance to antibiotics by respiratory pathogens has complicated the use of empirical treatment with traditional agents and a definitive bacteriological diagnosis and susceptibility testing would, therefore, be required for effective management of LRTI.

Antimicrobial susceptibility test performed for all GNB bacterial isolates in the current study showed that Gram- negative bacteria, susceptibility pattern was variable. In case of Pseudomonas spp Imipenem (84.09\%) was the most effective antibiotic followed by Ciprofloxacin (75\%), Colistin (72.72\%), Gentamicin (72.72\%), Amikacin, Levofloxcin (70.45\%). Klebsiella spp. was most sensitive to Colistin (80\%) followed by Imipenem $(67.50 \%)$ while Acinetobacter spp was sensitive to Colistin (85\%) only. Acinetobacter spp exhibited $100 \%$ resistance to all most all drugs means it is multidrug resistence. E. coli were sensitive to Imipenem (78.57\%) followed by PiperacillinTazobactam and Gentamicin (57.14\%) but all of them showed resistance to Amoxiclave, ampicillin. Enterobacter, Citrobacter, Steanotrophomanas spp. and Serratia spp were sensitive to Colistin, PiperacillinTazobactam and exhibit resistence to mostly 
antibiotics. In the similar study conducted by Neha garg et al., (2018) in which antibiotic susceptibility test of the isolates showed that Pseudomonas were sensitive to Imipenem (87.5\%) and similar to Trupti bajpai et al., (2013). In our study Colistin and Imipenem had shown greater activity against Klebsiella similar to study conducted by Kombade et al., (2014) and contrast to Lata baswanna et al., (2015) study in which Klebsiella was sensitive to amikacin and Ciprofloxacin.

The emergence of resistant strains poses a major threat to the patients globally. Inappropriate and irrational drug usage should be avoided. Owing to the increased concern which surrounds antibiotic resistance and the changing patterns of bacterial pathogens, the on-going surveillance of disease and a regular review of the management guidelines are critical. Educational campaigns have quite sensibly tried to convince both the doctors and the general public about the need to use appropriate, evidence based antibiotic treatment policy which is based on the infective organism. Ongoing community based studies are needed to identify the best management for individual patients. The therapy should be based on an aggressive diagnostic work up and the broad spectrum antimicrobial treatment which is guided by microbiological support.

\section{References}

Akingbade $\mathrm{O}$, Ogiogwa $\mathrm{J}$, Okerentugba $\mathrm{P}$, Innocent-Adiele $\mathrm{H}$, Onoh $\mathrm{C}$, Nwanze $\mathrm{J}$, et al., Prevalence and Antibiotic Susceptibility Pattern of Bacterial Agents Involved In Lower Respiratory Tract Infections in Abeokuta, Ogun State, Nigeria. Report and opinion. 2012; 4(5): 25-30

Bajpai T, Shrivastav G, Bhatambare G.S, Deshmukh A. B, Chitnis V. Microbiological profile of lower respiratory tract infections in neurological intensive care unit of tertiary care center from central India. Journal of basic and clinical pharmacy. 2013; 4 (3): 51-5
Betty A Forbes, Daniel F. Sahm and Alice S. Weissfeld. Bailey \& Scott's Diagnostic microbiology, 11 edition. Chapter- 18, 260283.

Clinical and Laboratory Standards Institute. Performance Standards for Antimicrobial Disk Susceptibility Tests. 9th ed. Approved standard. Wayne, PA: Clinical and Laboratory Standards Institute, 2018. (CLSI document no. M2-A9).

Dawadi S, Rao BS, Khan GM. Pattern of antimicrobial prescription and its cost analysis in respiratory tract infection. Kathmandu University Journal of Science, Engineering and Technology 2005; 1(1):1-5.

Egbagbe EE, and Mordi RM. Aetiology of Lower Respiratory Tract Infection in Benin City, Nigeria. Journal of Biomedical Sciences 2006; 5(2): 22-27.

Garg N. To Determine the Bacteriological Profile and Antibiotic Sensitivity Pattern of the Isolates Causing Ventilator Associated Pneumonia in ICU Patients. Int Arch BioMed Clin Res. 2018; 4(1):68-71.

Gauchan P, Lekhak B, Sherchan JB. The prevalence of lower respiratory tract infection in adults visiting Tribhuvan University Teaching Hospital. Journal of Nepal Health Research Council 2006; 3(2): 23-28.

Isenberg HD. Clinical Microbiology Procedures Handbook. 2nd ed. Washington, D.C: ASM Press 2004.

Kim JH, Park JK, Park EJ, Kang MW. Microbial pathogens and antibiotic susceptibility in community-acquired lower respiratory tract infection in Korea. Respiratory tract infection and their management 2005: 1197.

Kombade, S.P., and G.N. Agrawal Microbiological study of lower respiratory tract infections in ICU patient Int.J.Curr.Microbiol.App.Sci (2014) 3(8) 749-754

Lata baswanna galate \& Pradnya shankar rao gajbhiye, Microbiological profile and antibiogram pattern of lower respiratory tract infection: International Journal of Humanities, Arts, Medicine and Sciences ISSN 2348-0521 Vol. 3, Issue 4, Apr 2015, 16 
Mahon CR, Lehman DC, Manuselis G. Textbook of Diagnostic Microbiology, 3rd ed, Gopson paper Ltd: Noida; 2007: 914-924.

Mishra SK, Kattel HP, Acharya J, et al., Recent trend of bacterial aetiology of lower respiratory tract infections in a tertiary care centre of Nepal. Int J Infect Microbiol 2012; 1(1): $3-8$.

Navaneeth BV, and Belwadi MR. Antibiotic resistance among gram-negative bacteria of lower respiratory tract secretion in hospitalized patients. Indian J Chest Dis Allied Sci 2002; 44: 173-6.

Ndip, RN., Ntiege, EA., Ndip, LM., Nkwelang, G. Aoachere TK, Nkuo Akenj T. Antimicrobial resistance of bacterial agents of the upper respiratory tract of school children in Bueu, Cameroon. Journal of Health population and nutrition. 2008; 26: 397-404.

Nidhi Goel, Uma Chaudhary, Riru Aggrawal, Kiran Bala. Antibiotic sensitivity pattern of gram negative bacilli isolated from lower respiratory tract of ventilated patients of intensive care unit. Research Article.2002; 13: p148-51

Okesola, A.O., O.M. Ige Trends in Bacterial Pathogens of Lower Respiratory Tract Infections. Indian J Chest Dis Allied Sci 2008; 50: 269-272.

Olugbue V, Onuoha S. Prevalence and antibiotic sensitivity of bacterial agents involved in lower respiratory tract infections. International Journal of Biological and Chemical Sciences. 2011; 5(2)

Reddiah VP, and Kapoor SK. Acute lower respiratory infections in rural underfives. Indian J Pediar 1988; 55: 424-26.

Sclwyn BJ. The epidemiology of acute respiratory tract infections in young children: Comparison of findings from several developing countries. Rev Infect Dis 1990; 12 (Suppl 8): 870-88.

Shah BA, Singh G, Naik MA, Dhobi GN. Bacteriological and clinical profile of Community acquired pneumonia in hospitalized patients. Lung India. 2010 Apr; 27(2): 54-57.

Sharma J. A prospective study on microbiology of lower respiratory tract infection and antibiotic sensitivity profile with interest in Multidrug resistant and extended spectrum betalactamase strain. An academic dissertation (M.Sc.) submitted to the Central Department of Microbiology, Tribhuvan University, Kritipur, Kathmandu, Nepal 2004.

Sherchan JB, Gurung P, Bam DS, Sherchand JB. Multidrug resistant bacterial strains in lower respiratory tract infections, antibiotic sensitivity patterns and risk factors. Nepal J Sci Technol. 2012; 13(1): 157-63.

Sony Shrestha, Anju Acharya, Hari Prasad Nepal, Rajendra Gautam4, Shamshul Ansari, Goma Upadhyay and Avisekh Gautam: Lower respiratory tract pathogens and their antimicrobial susceptibility pattern in a medical hospital of central Nepal IJBAR (2013) 04 (05)

Veena Kumari H.B, Agarathna SN, Chandramuki A. Antimicrobial resistance pattern among Aerobic gram negative bacilli of Lower Respiratory Tract Specimens of Intensive Care Unit in a Neuro centre. Indian J Chest Allied Dis 2007; 49: 19-22.

World Health Organisation. Basic laboratory procedures in clinical Bacteriology. 2003; 2nd ed. Pp: 66-67

World Health Organization (WHO) (2004) The Global Burden of Disease, WHO headquater, Geneva, Switzerland.

\section{How to cite this article:}

Manjula J. Barbriya and Neelam Chauhan. 2018. Antimicrobial Susceptibility Pattern among Aerobic Gram Negative Bacilli of Lower Respiratory Tract Specimens of a Tertiary Care Hospital in Southern Rajasthan. Int.J.Curr.Microbiol.App.Sci. 7(06): 2537-2544. doi: https://doi.org/10.20546/ijcmas.2018.706.299 